Dept. of Food Hygiene, Fac. Vet. Med.,

Alex. Univ., Egypt.

\title{
PROBIOTICS AS A TOOL TO IMPROVE MICROBIAL QUALITY OF SOFT CHEESE
}

(With 4 Figures)

\author{
By \\ AMR AMER \\ (Received at 22/1/2011) \\ عمرو عبل المؤمن عامر
}

المدعمات الحيوية كأداة لتحسين الجودة الميكروبية للجبن الطري

تعتبر المدعمات الحيوية عند استخدامها لها تأثير فعال على صحة الإنسان حيث أنها تقلل من من فئن

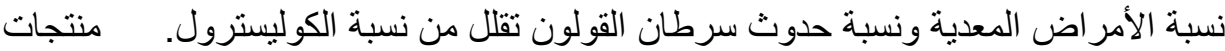

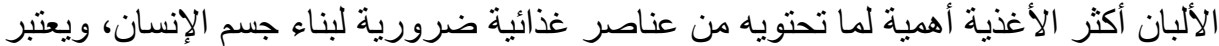

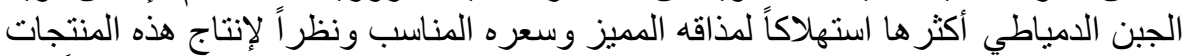

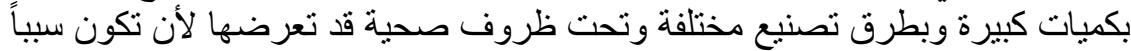

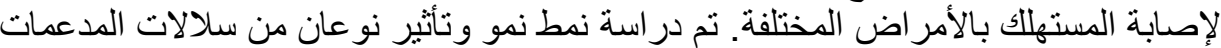

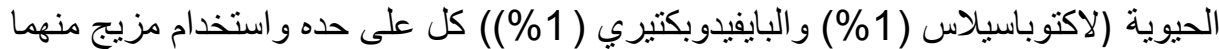

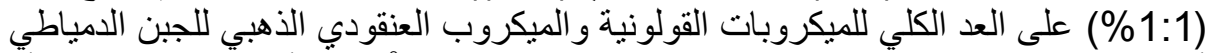

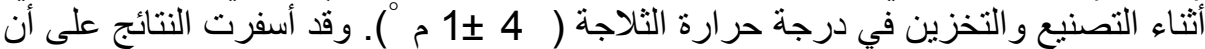

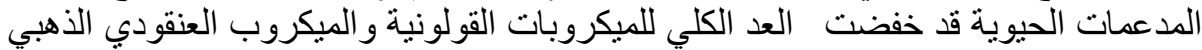

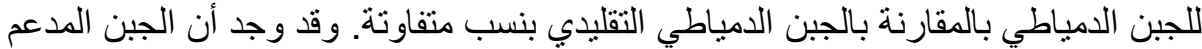

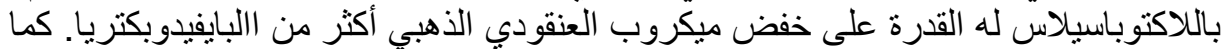

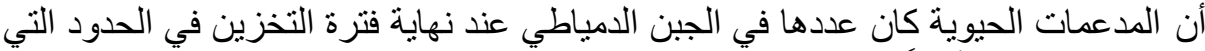
من خلالها تعطي نأثيراً ايجابيا على صحة الإنى الإنسان.

\section{SUMMARY}

Functional foods incorporating probiotic bacteria such as bifidobacteria and lactobacilli have a variety of beneficial health effects in human. The objective of the present study was to investigate the survival of L. acidophilus and Bifidobacterium lactis during manufacture and storage of Damietta cheese stored at $4 \pm 1^{\circ} \mathrm{C}$ in brine and to determine the effects of Lactobacillus acidophilus and Bifidobacterium lactis on the microbial quality of Damietta cheese. Cheese samples were examined for coliforms and Staphylococcus aureus counts. The results revealed a 
significant $(\mathrm{P}>0.05)$ differences in the counts of coliforms and S.aureus in the probiotic cheese with those in control cheese. The obtained results verify that using Lactobacillus acidophilus and Bifidobacterium lactis as probiotics had a greater inhibitory effect on coliforms and Staphylococcus aureus counts in cheese. Lactobacillus acidophilus probiotic cheese is more effective in inhibition of S.aureus than either probiotic cheese with Bifidobacterium lactis or combination of them ( $\mathrm{P}>0.05$ ). The final numbers of $L$. acidophilus and Bifidobacterium lactis were greater than the minimum $\left(10^{7} \mathrm{cfu} / \mathrm{g}\right)$, as suggested by Ishibashi and Shimamura (1993), required to produce health benefits claimed for probiotic cheese. The results showed that Damietta cheese can be an effective carrier of probiotics to consumer.

Key words: Probiotics, S.aureus, Coliforms, Damietta cheese

\section{INTRODUCTION}

There has been an increasing interest in dairy products containing specific bacterial species with potential health improving properties. Probiotic bacteria are defined as living microorganisms which upon ingestion in certain numbers exert health benefits beyond inherent basic nutrition (Ross et al., 2002). Health benefits for products containing live probiotic bacteria include alleviation of symptoms of lactose intolerance, treatment of diarrhea, anticarcinogenic properties, reduction in blood cholesterol and improvement in immunity (Shah, 2007). Consumption of high concentration of probiotic bacteria at $10^{7}$ viable cells per gram or per millilitre of product is required to confer health benefits (Ishibashi and Shimamura, 1993).

As in the case of any probiotic food, in order to exert their health benefits on the consumer's body, probiotic bacteria incorporated in cheese must be able to grow and/or proliferate in the human intestine and therefore should be able to survive during the passage through the gastrointestinal tract (GIT), which involves exposure to hydrochloric acid in the stomach and bile in the small intestine (Stanton et al., 2003).

The majority of probiotic foods already in the market, such as fermented milk and yoghurt are fresh products and are generally consumed within days or weeks of manufacture. Cheese may offer certain advantages over yoghurt-type products in terms of delivery of viable probiotics, such as the higher $\mathrm{pH}$ of the cheese, the higher fat 
content and more solid consistency of cheese may offer protection to the probiotics in the gastrointestinal tract (Stanton et al., 1998).

Studies showed that functional foods incorporating probiotic bacteria such as bifidobacteria and lactobacilli have a variety of beneficial health effects in human. Due to the repeated therapeutic effects of these organisms, Japan and several European countries have been actively involved in the development and application of bifidobacteria (Gomes and Malcata, 1999). Such products are gaining more widespread popularity and acceptance throughout the world, and predictions are that the global market for this type of food will grow rapidly in the coming years (Ross et al., 2000).

In fact, cheese provides a valuable alternative to fermented milks and yogurts as a food vehicle for probiotic delivery, due to certain potential advantages. It creates a buffer against the high acidic environment in the gastrointestinal tract, and thus creates a more favorable environment for probiotic survival throughout the gastric transit, due to higher $\mathrm{pH}$. Moreover, the dense matrix and relatively high fat content of cheese may offer additional protection to probiotic bacteria in the stomach (Ross et al., 2002; Bergamini et al., 2005). This finding was confirmed by Sharp et al. (2008).

Damietta cheese is a soft white salty cheese made primarily in Egypt and other Middle Eastern countries. It is typically made from buffalo milk, cow milk, or a mixture. Unlike Feta and other white cheeses, salt is added directly to the milk, before rennet is added.

The development of Damietta cheese containing Bifidobacteria was demonstrated by Effat (2000); El-Zayat and Osman (2001) and Shehata et al. (2001) and reported that the resultant cheese had the highest scores for organoleptic properties. Mehanna et al. (2002) prepared probiotic soft cheese with highly acceptable qualities and the authors considered soft cheese to be a good source for delivering these probiotic bacteria to consumers.

A number of studies have addressed the development of probiotic cheeses including fresh cheese (Gomes and Malcata, 1998; Gomes et al., 1998), semi hard cheese (Bergamini et al., 2006) and white-brined cheese (Özer et al., 2009). These studies have demonstrated that cheeses have a great potential as a carrier to deliver probiotic bacteria to the consumer. Most publications concerning incorporation of probiotic bacteria into cheeses have focused only on their survival during manufacture and storage. So, this study was 
planned to declare the effect of probiotics in improving the microbial quality of soft cheese.

\section{MATERIALS and METHODS}

\subsection{Cultures}

L. acidophilus and Bifidobacterium lactis were obtained from the Faculty of Agriculture, Alexandria University. L. acidophilus was activated by growing two times at $30{ }^{\circ} \mathrm{C}$ overnight in $120 \mathrm{mg} / \mathrm{ml}$ sterile reconstituted skim milk (RSM) containing $20 \mathrm{mg} / \mathrm{ml}$ glucose and 12 $\mathrm{mg} / \mathrm{ml}$ yeast extract. Bifidobacterium lactis was sub-cultured similarly using $10 \mathrm{ml} / \mathrm{ml}$ inocula in sterile RSM supplemented with $0.5 \mathrm{mg} / \mathrm{ml} \mathrm{L-}$ cysteine hydrochloride (Sigma-Aldrich, St. Louis,MO, USA).

\subsection{Cheese preparation (Fahmi and Sharara, 1950):}

Damietta white cheese was manufactured in the pilot plant (Department of Food Hygiene; Faculty of Veterinary Medicine; Alexandria University). Eighty liters antibiotic-free whole buffalo milk (pH 6.8) was obtained from the Veterinary Medicine Practice Farm of Alexandria University. Milk was pasteurized at $72^{\circ} \mathrm{C}$ for $2 \mathrm{~min}$. After the milk was cooled to $32^{\circ} \mathrm{C}, \mathrm{Cacl}_{2}(0.02 \%)$ were added into the milk. Milk was transferred to stainless steel cheese vats, each containing $20 \mathrm{~L}$ of milk. The first vat, the probiotic cheese, milk was inoculated with L. acidophilus $(1 \mathrm{ml} / 100 \mathrm{ml})$, the second one was inoculated with Bifidobacterium lactis $(1 \mathrm{ml} / 100 \mathrm{ml})$, the third vat was inoculated with combination of L. acidophilus $(1 \mathrm{ml} / 100 \mathrm{ml})$ and Bifidobacterium lactis $(1 \mathrm{ml} / 100 \mathrm{ml})$ while the last one was used as a control. Chymosin was added to each cheese vat at a level sufficient to coagulate the milk in 60 $\min (50 \mathrm{ml} / 20 \mathrm{~L})$. The coagulum was cut with a sterile knife into small cubes and the curds were allowed to rest in the whey for 5-10 min. The curds ( $\mathrm{pH}$ 6.4) were transferred to stainless-steel moulds lined with cheesecloth. The surfaces of the cheeses were covered with cheesecloth, drained without pressure for $20 \mathrm{~min}$, and pressed (40 kg weights for 100 $\mathrm{L}$ milk) for $3 \mathrm{~h}$. The weights were removed, the cheese cloths opened and the cheese mass cut into cubic pieces. The cubes were brine-salted $(5 \%, \mathrm{w} / \mathrm{w}, \mathrm{NaCl})$ for $13 \mathrm{~h}$. After brine salting, each batch was stage of manufacture. Then each batch stored at $4^{\circ} \mathrm{C}$ for 60 days. held at room temperature $\left(20^{\circ} \mathrm{C}\right)$ for $6 \mathrm{~h}$; this is described as the resting

\subsection{Sampling}

Raw milk, fresh curd and cheese samples were examined for coliforms, S.aureus, L. acidophilus and Bifidobacterium lactis bacteria. 
Cheese samples were taken for bacterial enumeration at 10, 20, 30, 40, 50 and 60 days of storage.

\subsection{Microbiological analysis}

From each cheese type, $10 \mathrm{~g}$ cheese were transferred into a sterile bag under aseptic conditions and homogenized in $90 \mathrm{ml}$ of sterile Trisodium citrate solution $2 \%$ for 2 min using a Lab blender 400 stomacher. Serial dilutions were prepared by adding $1 \mathrm{ml}$ to $9 \mathrm{ml}$ sterile peptone water $(0.1 \%)$. All samples were tested for:

1 - Counts of L. acidophilus and Bifidobacterium lactis MRS agar (pH 5.4) (Oxoid) and incubated anaerobically (GasPak System, Oxoid) at $37^{\circ} \mathrm{C}$ for 3 days.

2 - Coliforms count (MPN/g) was done according to Harrigan (1998).

3 - Staphylococcus aureus count was done according to ICMSF (1986).

\subsection{Statistical analysis}

All samples were analyzed in duplicate and the experiment was repeated three times by using SPSS 10 statistical software (SPSS, 1999).

\section{RESULTS}

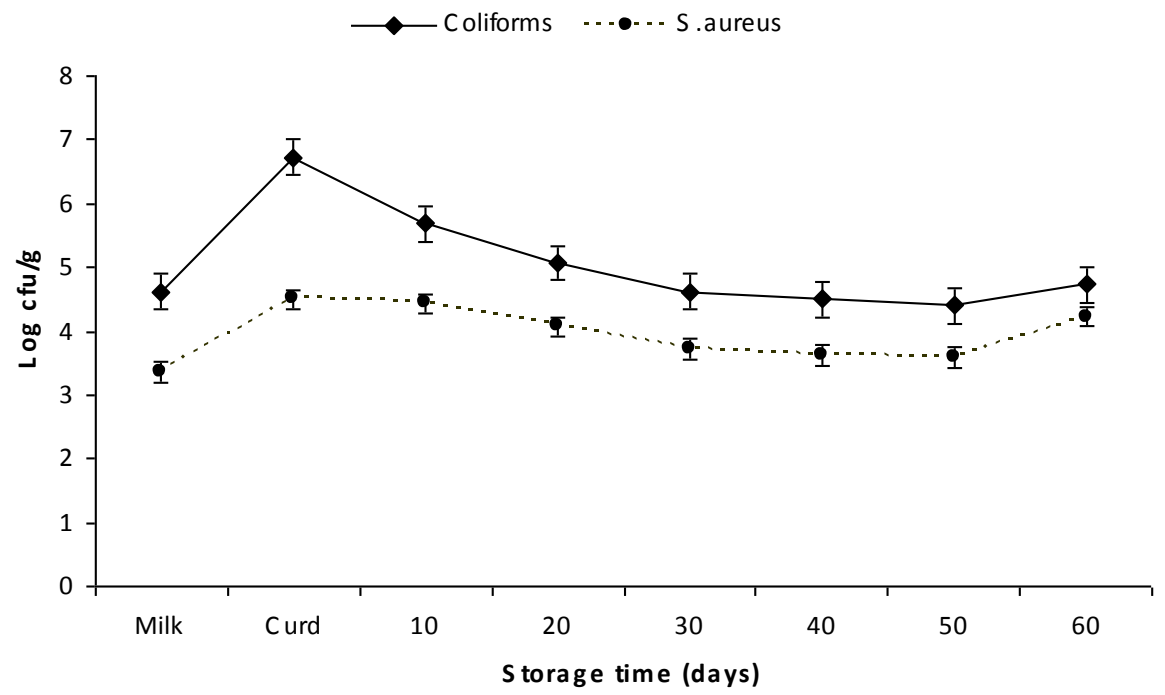

Fig. 1: The growth patterns of coliforms and Staphylococcus aureus in Damietta cheese samples stored at $4^{\circ} \mathrm{C}$ 

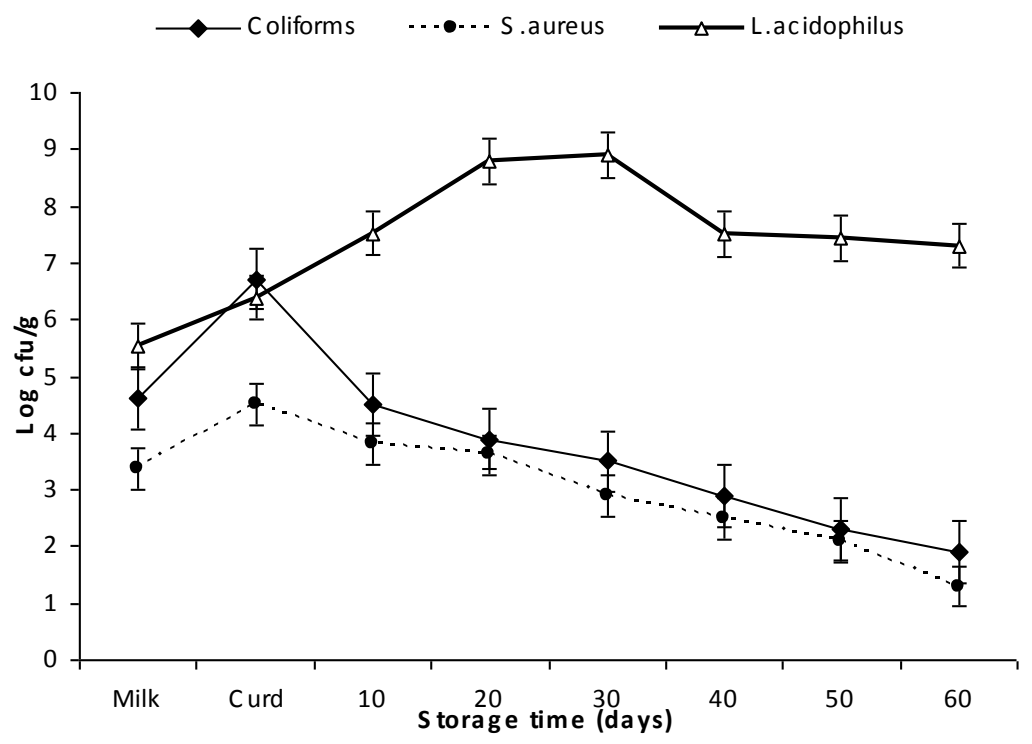

Fig. 2: The growth patterns of coliforms and Staphylococcus aureus in Probiotic Damietta cheese samples with L. acidophillus stored at $4^{\circ} \mathrm{C}$

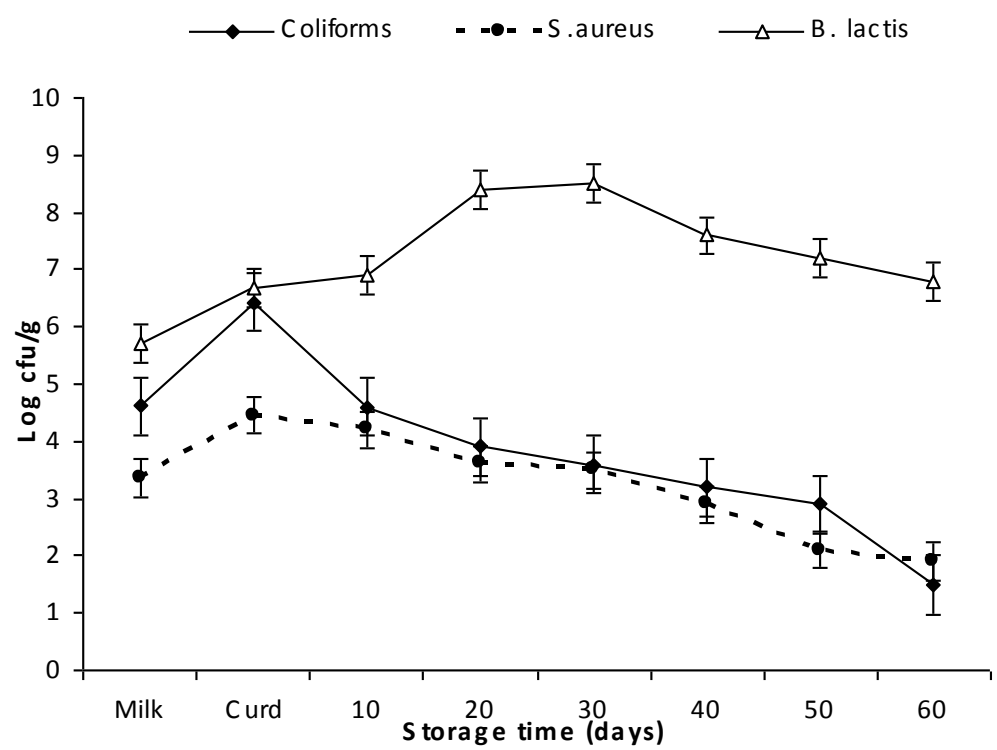

Fig. 3: The growth patterns of coliforms and staphylococcus aureus in probiotic Damietta cheese samples with $\mathrm{B}$. lactis stored at $4{ }^{\circ} \mathrm{C}$ 

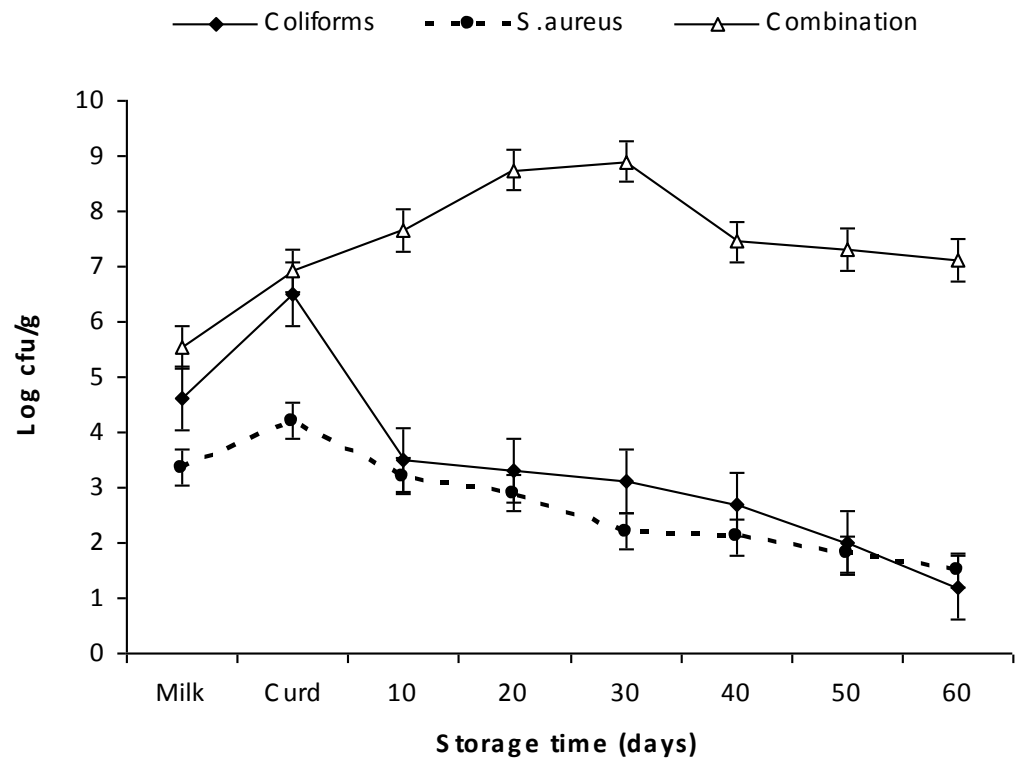

Fig. 4: The growth patterns of coliforms and Staphylococcus aureus in probiotic Damietta cheese samples with combination of L. acidophillius and B.lactis stored at $4^{\circ} \mathrm{C}$

\section{DISCUSSION}

The results presented in Figure 1 verify the growth pattern of coliforms and Staphylococcus aureus in Damietta cheese samples during storage at $4^{\circ} \mathrm{C}$ as their counts in milk used in manufacture were 4.61 and $3.36 \mathrm{log} \mathrm{cfu} / \mathrm{g}$, respectively. Their counts increased gradually to reach maximum number at the $20^{\text {th }}$ day of storage period followed by a gradual decrease in count by the end of storage period reaching 4.74 and 4.23 $\log \mathrm{cfu} / \mathrm{g}$, respectively. These results were substantiated with those obtained by Aiad (2002) and Amer and Ewina (2003).

Coliforms, in dairy products, played an important role in microbiological analysis on accounting of their significance as indicator organisms for pinpointing the unhygienic condition during processing, handling and distribution. The presence of S.aureus in soft cheese may originate from skin, mouth and/or nose of workers handled the food. $S$. aureus is a good indicator of the personal hygiene of workers with respiratory infection and suppuration (Kamat et al., 1991). 
The growth of S.aureus in food products is a potential public health hazard since many strains, in favorable growth conditions produce thermostable enterotoxins which cause intoxication food poisoning if ingested as well as neurotoxins which act on vomiting centers in the brain via the vagus nerve (Adams and Moss, 2000). However, Luca et al. (1997) reported that S.aureus was the leading cause of foodborne intoxication, and the minimum infection dose was $10^{5}-10^{7} / \mathrm{g}$ or $1-20 \mu \mathrm{g}$ enterotoxin /person.

The numbers of L. acidophilus in the probiotic cheese during storage are shown in Figure 2. Initial numbers of $L$. acidophilus inoculated into the milk were $5.54 \mathrm{log} \mathrm{cfu} / \mathrm{ml}$, but they grew rapidly during the first 10 days of storage and reached to $7.52 \mathrm{log} \mathrm{cfu} / \mathrm{g}$ in cheese. Rapid growth of $L$. acidophilus might be due to the fermentation of lactose. It is well known that lactobacilli grow best under acidic conditions (Kandler and Weiss, 1986). High moisture and low salt content in the centre of the cheese might support L. acidophilus for 10 days.

The viable cell numbers of $L$. acidophilus began to decrease after 30 days of storage, because of the decrease in moisture level, subsequently increase in salt content, and the low storage temperature $\left(4^{\circ} \mathrm{C}\right)$. Although L. acidophilus decreased until the end of the storage period, it did not decrease below $7.3 \mathrm{log}$ cfu /g cheese. As indicated earlier, it is necessary to maintain the viability of L. acidophilus at $7 \mathrm{log}$ cfu /g of cheese, to call the cheese probiotic (Ishibashi and Shimamura, 1993). Also, it was stated that a minimal concentration of $10^{7} \mathrm{cfu} / \mathrm{g}$ or ml of food should be present at the moment of intake to assure a favorable impact of probiotics on a consumer's health (De Vuyst, 2000).

The present results are similar to the results obtained by Bergamini et al. (2005) who found a viability of $10^{9} \mathrm{cfu} / \mathrm{g}$ in a semi-hard Argentinean cheese produced with Lactobacillus paracase $i$ in a substrate composed of milk and milk fat on day 60. Our results are also in accordance with previous studies conducted for Turkish Beyaz cheese (Akgün, 1995; Kasimoglu et al., 2004).

The results in Figure 2 revealed that a gradual decrease in numbers of coliforms and S.aureus occurred during the prolonged shelflife of Damietta cheese kept at $4 \pm 1^{\circ} \mathrm{C}$. Coliforms and S.aureus achieved the minimum counts on the $60^{\text {th }}$ day of storage reaching 1.9 and $1.3 \mathrm{log}$ cfu/g, respectively. There were significant $(\mathrm{P}>0.05)$ differences in the 
counts of Coliforms and S.aureus in the probiotic cheese with those in control cheese.

Data revealed in that Damietta cheese (control) showed high Staphylococcus aureus count than that probiotic one. These results suggested that probiotic bacteria incorporated in the manufacture of Damietta cheese reducing the growth of S.aureus in cheese is due to facultative anaerobic conditions created by probiotic bacteria in fermented food (Batish et al., 1997), or due to their lactic and organic acids production, decreasing the $\mathrm{pH}$ of the growth environment (Caplice and Fizgerald, 1999).

The high antimicrobial activity of Lactobacilli is associated with the production and synergistic activity of organic acids and hydrogen peroxide, whereas the antagonistic activity of Lactobacilli against Gramnegative and Gram -positive bacteria dependent on the fermentation group of Lactobacilli (Annuk et al., 2003). Axelsson et al. (1989) and Chung et al. (1989) reported that some strains of Lactobacilli produced $\beta$-hydroxylpropion aldehyde induced from glycerol which had a wide antimicrobial spectrum against Gram-negative and Gram -positive bacteria. This may be explaining the present findings.

The survival of the Bifidobacterium lactis in Damietta cheese over 60 days of storage was studied. It was seen that, in the first 10 days, an initial increase in numbers, was observed to reach the maximum numbers after 30 days of storage $8.5 \mathrm{log} \mathrm{cfu} / \mathrm{g}$ and then in the period 40 60 days it declines reaching $6.78 \mathrm{log} \mathrm{cfu} / \mathrm{g}$ (Figure, 3). Given a consumption of a nominal one serving ( $30 \mathrm{~g}$ ) of cheese/day, the intake of each Bifidobacterium would be between $10^{9}$ and $10^{10}$ /day that is well above the levels suggested as providing therapeutic benefits (Boylston et al., 2004).

The data presented in Figure 3 showed the growth pattern of coliforms and S.aureus counts occurred during the prolonged shelf-life of Damietta cheese kept at $4 \pm 1^{\circ} \mathrm{C}$. Coliforms and S.aureus reached lowest counts on the $60^{\text {th }}$ day of storage reaching 1.5 and $1.9 \log \mathrm{cfu} / \mathrm{g}$, respectively. There were significant $(\mathrm{P}>0.05)$ differences in the counts of coliforms and S.aureus in the probiotic cheese than those in control cheese.

Bifidobacteria produce bacteriocins which are active against S. aureus (Cotter et al., 2005). Many Bifidobacteria produce bacteriocins with rather broad spectra of inhibition and several 
Bifidobacteria bacteriocins offer potential applications for food preservation (Marshall and Tamime, 1997; Galvez et al., 2007).

It is evident from Figure 4 that coliforms and $S$. aureus counts were decreased in probiotic cheese with combination of Lactobacillus acidophilus and Bifidobacterium lactis $(1: 1 \%)$ stored at $\left(4 \pm 1^{\circ} \mathrm{C}\right)$ reaching 1.2 and $1.5 \log \mathrm{cfu} / \mathrm{g}$, respectively, by the end of storage period. There were significant $(\mathrm{P}>0.05)$ differences in the counts of coliforms and S.aureus in the probiotic cheese with combination of Lactobacillus acidophilus and Bifidobacterium lactis $(1: 1 \%)$ than those in control cheese.

The obtained results verified that combination of Lactobacillus acidophilus and Bifidobacterium lactis (1:1\%) had a greater inhibitory effect on coliforms count in cheese than on using each one alone. Lactobacillus acidophilus probiotic cheese is more effective in inhibition of S.aureus than either probiotic cheese with Bifidobacterium lactis or combination of both $(\mathrm{P}>0.05)$.

The results show that cheeses can be an effective carrier of probiotic to consumer. Cheeses also have a number of advantages over fresh fermented products such as yoghurt as a delivery system for viable probiotics to consumer (Ong et al., 2006). Cheeses have higher $\mathrm{pH}$, a more solid consistency, a higher fat content and a higher buffering capacity than yoghurt; thus would offer more protection to probiotic organisms during storage and in the gastrointestinal tract (Kailasapathy and Chin, 2000; Vinderola et al., 2002). Addition of $5 \mathrm{~g}$ cheese to $10 \mathrm{ml}$ of gastric juice increased the $\mathrm{pH}$ from 2.00 to 4.74 , whereas $5 \mathrm{~g}$ of yoghurt increased the $\mathrm{pH}$ to only 3.65 (Gardiner et al., 1998). Buriti et al. (2005) tested the supplementation of Minas fresh cheese with L. paracasei. The cheeses studied by the authors presented populations above $10^{6} \mathrm{cfu} / \mathrm{g}$ during cheese production, and population increased during the whole storage, reaching $10^{8} \mathrm{cfu} / \mathrm{g}$ after 21 days.

It could be concluded that, this inhibitory effect of probiotic and potentially probiotic strains can be helpful for the use as biopreservatives in the production of cheeses. These strains, besides contributing together with the starter culture for the production of organic acids, may also produce other antimicrobial compounds, including hydrogen peroxide, alcoholic compounds, diacetyl, and bacteriocins. This inhibitory activity creates a hostile environment for pathogens and spoilage organisms. 


\section{REFERENCES}

Adams, M.S. and Moss, M.O. (2000): Food Microbiology 2Ed. Royal Society of Chemistry. Thomas Graham House, Science Park, Milton Road Cambridge CB40WF, UK.

Aiad, A.A. (2002): Criteria for evaluation of locally manufactured dairy products. Ph.D. Thesis, Fac. Vet. Med., Alexandria Univ.

Akgün, S. (1995): Beyaz peynir uretiminde Lactobacillus sake'nin starter kültür olarak kullanilmasi. Ankara U.niversitesi Veteriner Fak. ultesi Dergisi, 42, 271-279.

Amer, A.A. and Ewina, M.A. (2003): Microbial profile of street-vended kareish cheese. The First International Scientific Conference, Fac. Vet. Med., Tanta University, Kafr El-Sheikh, May 6-8, 2003.

Annuk, H.; Scheptova, J.; Kullisaar, T.; Songisepp, E.; Zilmer, M. and Mikelsaar, M. (2003): Characterization of intestinal Lactobacilli as putative probiotic candidates. J. Applied Microbiol., 94:403.

Axelsson, L.; Chung, T.C.; Dobrogosz, W.J. and Lindgren, S.E. (1989): Production of a broad spectrum antimicrobial substance by Lactobacillus reuteri. Microbiol. Ecological Health Disease. 2:131.

Batish, V.K.; Roy, U.; Lal, R. and Grover, S. (1997): Antifungal attributes of lactic acid bacteria: A review. Crit. Rev. Biotechnol., 17: 209.

Bergamini, C.V.; Hynes, E.R. and Zalazar, C.A. (2006): Influence of probiotic bacteria on the proteolysis profile of a semi-hard cheese. International Dairy Journal, 16(8): 856-866.

Bergamini, C.V.; Hynes, E.R.; Quiberoni, A.; Suarez, V.B. and Zalazar, C.A. (2005): Probiotic bacteria as adjunct starters: influence of the addition methodology on their survival in a semi-hard Argentinean cheese. Food Research International, 38(5): 597-604.

Boylston, T.D.; Vinderola, C.G.; Ghoddusi, H.B. and Reinheimer, J.A. (2004): Incorporation of bifodobacterium into cheeses: challenges and rewards. International Dairy Journal 14: 375-387.

Buriti, F.C.A.; DaRocha, J.S. and Saad, S.M.I. (2005): Incorporation of Lactobacillus acidophilus in Minas fresh cheese and its 
implications for textural and sensorial properties during storage. International Dairy Journal, 15: 1279-1288.

Caplice, E. and Fizgerald, G.F. (1999): Food fermentation: Role of Microorganisms in food production and preservation. Inter. J. Food Microbiol., 50: 131.

Chung, T. C.; Axelsson, L.; Lindgren, S.E. and Dobrogosz, W.J. (1989): In vitro studies on reuterin synthesis by Lactobacillus reuteri. Microbiol. Ecological Health Disease. 2: 137.

Cotter, P.D.; Hill, C. and Ross, R.P. (2005): Bacteriocins: developing innate immunity for food. Nat. Rev. Microbiol. 3: 777-788.

De Vuyst, L. (2000): Technology aspects related to the application of functional starter cultures. Food Technology and Biotechnology, 38: 105-112.

Effat, B.A. (2000): Effect of using Lactobacillus reuteri with other with other probiotic culture on the quality of Domiati cheese. Minufiya J. Agric. Res. 25: 445.

El-Zayat, A.J. and Osman, M.M. (2001): The use of probiotic in Tallaga cheese. Egyptian J. Dairy Sci., 29: 99.

Fahmi, A.H. and Sharara, H.A. (1950): Studies on Egyptian Domiati cheese. J. Dairy Res. 1, 17,3: 312.

Galvez, A.; Abriouel, H.; Lopez, R.L. and Ben, O.N. (2007): Bacteriocinbased strategies for food biopreservation. Int. J. Food Microbiol. 120: 51-70.

Gardiner, G.; Stanton, C.; Lynch, P.B.; Collins, J.K.; Fitzgerald, G. and Ross, R.P. (1998): Evaluation of Cheddar cheeses as a food carrier for delivery of a probiotic strain to the gastrointestinal tract. Journal of Dairy Science, 82: 1379-1387.

Gomes, A.M.P. and Malcata, F.X. (1998): Development of probiotic cheese manufactured from goat milk: Response surface analysis via technological manipulation. Journal of Dairy Science, 81: 1492-1507.

Gomes, A.M.P. and Malcata, F.X. (1999): Bifidobacterium spp. and Lactobacillus acidophilus: biological, biochemical, technological and therapeutical properties relevant for use as probiotics. Trends in Food Science and Technology, 10: 139-157.

Gomes, A.M.P.; Vieira, M.M. and Malcata, F.X. (1998): Survival of probiotic strains in a cheese during ripening: Simulation of rates of salt diffusion and microorganism survival. Journal of Food Engineering, 36: 281-301. 
Harrigan, W.F. (1998): Laboratory Methods in Food Microbiology. Academic Press, 525 B Street, Suit 1900, San Diego, California 92101-4495, USA.

"International Committee of Microbiological Specification for Foods" (1986): Microorganisms in foods and sampling for microbiological analysis principles and specific applications.

Ishibashi, N. and Shimamura, S. (1993): Bifidobacteria research and development in Japan. Food Technology, 47: 126-135.

Kailasapathy, K. and Chin, J. (2000): Survival and therapeutic potential of probiotic organisms with reference to Lactobacillus acidophilus and Bifidobacterium spp. Immunology and Cell Biology, 78: 80-88.

Kamat, M.Y.; Sulebele, G. and Nirupama, S. (1991): A comparative evaluation of media for enumeration of enterotoxigenic staphylococci by selective enrichment technique. J. Food Sci. Technol. India, 28(6): 381-383.

Kandler, O. and Weiss, N. (1986): Lactobacillus. In P. H. A. Sneath, N.S. Mair, M. E. Sharpe, \& J. G. Holt (Eds.), Bergey's Manual of Systematic Bacteriology (pp. 1209-1221). Los Angeles: Williams \& Wilkins.

Kasimoglu, A.; Göncü oğlu, and Akgün, M. (2004): Probiotic white cheese with Lactobacillus acidophilus. International Dairy Journal, 14: 1067-1073.

Luca, G.; Zanetti, F.; Stamp, S. and De Luca, G. (1997): Staphylococcus aureus in dairy products in the Bologna area. Int. J. Food Microbiol., 35(3): 267-270.

Marshall, V.M. and Tamime, A.Y. (1997): Starter cultures employed in the manufacture of biofermented milks. International J. Dairy Technol., 50: 35.

Mehanna, Nayra, S.; Sharaf, O.M.; Ibrahim, G. A. and Tawfik, N.F. (2002): Incorporation and viability of some probiotic bacteria in functional dairy food. 1. Soft cheese. Egyptian J. Dairy Sci., 30: 217.

Özer, B.; Kirmaci, H.A.; Senel, E.; Atamer, M. and Hayalog $\urcorner$, A. (2009): Improving the viability of Bifidobacterium bifidum BB-12 and Lactobacillus acidophilus LA-5 in white-brined cheese by microencapsulation. International Dairy Journal, 19: 22-29.

Ong, L.; Henriksson, A. and Shah, N.P. (2006): Development of probiotic cheddar cheese containing Lactobacillus acidophilus, 
Lb. casei, Lb. paracasei and Bifidobacterium spp. and the influence of these bacteria on proteolytic patterns and production of organic acid. International Dairy Journal, 16: 446-456.

Ross, R.P.; Fitzgerald, G.; Collins, K. and Stanton, C. (2002): Cheese delivering biocultures- probiotic cheese. The Australian Journal of Dairy Technology, 57: 71-78.

Ross, R.P.; Stanton, C.; Hill, C.; Fitzgerald, G.F. and Coffey, A. (2000): Novel cultures for cheese improvement. Trends in Food Science \& Technology, 11: 96-104.

Shah, N.P. (2007): Functional cultures and health benefits. International Dairy Journal, 17(11): 1262-1277.

Sharp, M.D.; McMahon, D.J. and Broadbent, J.R. (2008): Comparative evaluation of yogurt and low-fat Cheddar cheese as delivery media for probiotic Lactobacillus casei. Journal of Food Science, 73(7), 375-377.

Shehata, A.E.; El-Nawawy, M.A. and El-Denany, Y. (2001): Production of soft cheese with health benefits. Proc. $8^{\text {th }}$ Egyptian Conference. Dairy Sci Technol., 635-651.

SPSS (1999): SPSS 10 for windows. Chicago, IL: SPSS Inc.

Stanton, C.; Desmond, C.; Coakley, M.; Collins, J.K.; Fitzgerald, G. and Ross, R.P. (2003): Challenges facing development of probioticcontaining functional foods. In E. R. Farnworth (Ed.), Handbook of fermented functional foods (pp. 27e58). Boca Ranton, LA, USA: CRC Press.

Stanton, C.; Gardiner, G.; Lynch, P.B.; Collins, J.K.; Fitzgerald, G. and Ross, R.P. (1998): Probiotic cheese. International Dairy Journal, 8: 491-496.

Vinderola, C.G.; Mocchiutti, P. and Reinheimer, J.A. (2002): Interactions among lactic acid starter and probiotic bacteria used for fermented dairy products. Journal of Dairy Science, 85: 721-729. 